
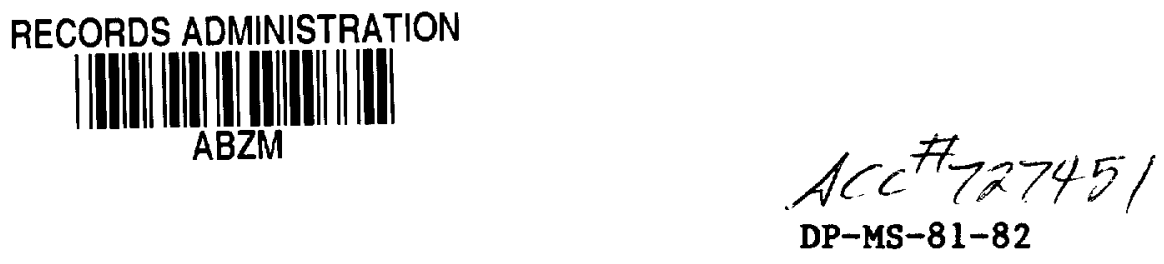

\title{
TRITIUM DEPOSITION IN PINE TREES AND SOIL FROM ATMOSPHERIC RELEASES OF MOLECULAR TRITIUM
}

by

C1yde W. Sweet* and Charles E. Murphy, Jr.

E. I. du Pont de Nemours \& Co. Sava nnah River Laboratory

Aiken, South Carolina 29808

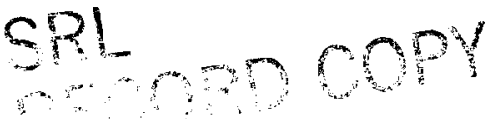

A paper proposed for publication in Enviromental Science and Technology

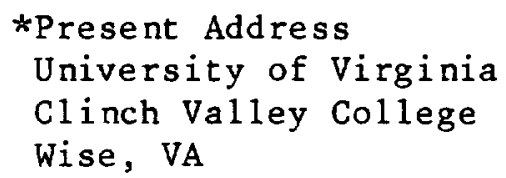

This paper was prepared in connection with work done under Contract No. DE-AC09-76SR00001 with the U.S. Department of Energy. By acceptance of this paper, the publisher and/or recipient acknowledges the U.S. Government's right to retain a nonexclusive, royalty-free license in and to any copyright covering this paper, along with the right to reproduce and to authorize others to reproduce all or part of the copyrighted paper. 
This document was prepared in conjunction with work accomplished under Contract No.

DE-AC09-76SR00001 with the U.S. Department of Energy.

\section{DISCLAIMER}

This report was prepared as an account of work sponsored by an agency of the United States Government. Neither the United States Government nor any agency thereof, nor any of their employees, makes any warranty, express or implied, or assumes any legal liability or responsibility for the accuracy, completeness, or usefulness of any information, apparatus, product or process disclosed, or represents that its use would not infringe privately owned rights. Reference herein to any specific commercial product, process or service by trade name, trademark, manufacturer, or otherwise does not necessarily constitute or imply its endorsement, recommendation, or favoring by the United States Government or any agency

thereof. The views and opinions of authors expressed herein do not necessarily state or reflect those of the United States Government or any agency thereof.

This report has been reproduced directly from the best available copy.

Available for sale to the public, in paper, from: U.S. Department of Commerce, National Technical Information Service, 5285 Port Royal Road, Springfield, VA 22161, phone: (800)

553-6847, fax: (703) 605-6900, email: orders@ntis.fedworld.gov online ordering: http://www.ntis.gov/ordering.htm

Available electronically at http://www.doe.gov/bridge

Available for a processing fee to U.S. Department of Energy and its contractors, in paper, from: U.S. Department of Energy, Office of Scientific and Technical Information, P.O. Box 62, Oak Ridge, TN 37831-0062, phone: (865 ) 576-8401, fax: (865) 576-5728, email: reports@ adonis.osti.gov 
DP-MS-81-82

\section{TRITIUM DEPOSITION IN PINE TREES AND SOIL FROM ATMOSPHERIC RELEASES OF MOLECULAR TRITIUM*}

by

Clyde W. Sweet*t and Charles E. Murphy, Jr.

E. I. du Pont de Nemours \& Co.

Savannah River Laboratory

Aiken, South Carolina 29808

\section{ABSTRACT}

Much of the tritium found in soil and leaf litter near a chemical separations facility is incorporated into soil organic matter in a stable, non-exchangeable form. Formation of this "bound" tritium seems to result from the uptake of molecular tritium (HT) by living pine needles. A deposition velocity $\left(V_{d}\right)$ for HT of $1.2 \times 10^{-5} \mathrm{~cm} / \mathrm{sec}$ was measured in pine needles. About $1 \%$ of the tritium deposited in this way is converted into organic matter. Soil and litter microbes convert HT to HTO more rapidly $\left(V_{d}=0.01 \mathrm{~cm} / \mathrm{sec}\right)$, but no measurable organic tritium is formed.

* The information contained in this article was developed during the course of work under Contract No. DE-AC09-76SR00001 with the U.S. Department of Energy.

** Present Address University of Virginia Clinch Valley College Wise, VA 


\section{Int roduction}

Starting with the first test of a thermonuclear weapon in 1952, man's activities have introduced tritium into the global enviroment. About $99 \%$ of this tritium is in the form of tritiated water (HTO), most of which is now in the oceans. Much of the remaining tritium is in the elemental form (HT). This form of tritium makes up over $50 \%$ of the tritium in the troposphere (1). The global inventory of molecular tritium has been relatively constant in recent years (2). However, tritium levels may increase in the future because of increases in nuclear fuel reprocessing activities and increased tritium use in consumer products. In addition, very large amounts of molecular tritium could be used in fusion power plants so that development of this technology would also increase atmospheric HT levels.

At the present time, little is known about the deposition and enviromental cycling of molecular tritium. Due to its low reactivity and low solubility in water, HT is considered to be a less serious radiological hazard than HTO, which is readily absorbed by living organisms. However, experiments with soil $(3,4)$ have indicated that HT is readily oxidized to HTO by soil microorganisms under enviromental conditions. There is some evidence that pine trees $(5,6)$ can also convert HT to HTO, but the rate is much less than that in soil. Relatively high levels of tritium, have been found in soil and plants after large accidental releases of HT to the atmosphere (7). 
In this paper, the pattern of tritium deposition in soil, litter, and vegetation in forested areas surrounding a nuclear separations facility is examined. The significance of this pattern in relation to HT metabolism by pines and soil microbes is discussed.

\section{Forms of Tritium}

Tritium can be present in vegetation and soil as a constituent of water, organic matter, or soil minerals. The tritium in vegetation and soil samples that is easily removed by evaporation at low temperature or by freeze drying is often designated as "free tritium." Tritium that is associated with organic matter or soil minerals is more difficult to remove from samples and is often designated "bound" tritium. Nearly all of the bound tritium can be removed by heating and combustion in a furnace.

The bound tritium fraction of soil or vegetation can be further divided into an exchangeable bound fraction and a nonexchangeable bound fraction. The exchangeable fraction will rapidly come into equilibrium with the specific activity of the tritiated water in its environment, while the non-exchangeable bound fraction will retain the specific activity of the materials from which it was synthesized. Exchangeable tritium can be removed from a sample by repeated washing with tritium free water.

In the experiments described below, free tritium is defined as tritium separated from the sample as water by freeze drying. Tritium collected as water from samples combusted in a high 
temperature oven $\left(700^{\circ} \mathrm{C}\right)$ immediately after freeze drying is designated "total bound" tritium. Tritium collected as tritiated water from samples combusted in a high temperature oven, after repeated freeze drying and washing with low tritium water, is designated "non-exchangeable bound" tritium. The tritium removed from the sample by washing after freeze drying is designated "exchangeable bound" tritium.

\section{Methods}

Ten sampling locations were chosen between 0.5 and $12 \mathrm{~km}$ from the H-Area chemical separation facility at the Savannah River Plant (SRP) near Aiken, South Carolina. This facility is a source of both HT and HTO. Sampling sites were chosen which were away from SRP reactor areas because the reactors are also HTO sources. Soil cores and leaf litter samples were taken between September 1979 and August 1980. Soil cores were sectioned into $5 \mathrm{~cm}$ segments and stored frozen in glass jars before processing. Soil, litter, and pine needle samples were freeze-dried overnight. Water removed by freeze-drying was collected in a cold trap and analyzed for tritium by liquid scintillation counting (LSC). The dried samples were then placed in a combustion furnace. Water was collected in a cold trap and analyzed for tritium by LSC.

Tritium concentrations in atmospheric moisture are routinely determined by the Health Protection Department at SRP at a number of stations. At each station, air is continuously pulled through a silica gel column. Biweekly, composite samples are analyzed for 
tritium by LSC. Averages of atmospheric moisture for 1979 and early 1980 were compared with the tritium concentrations in the soil cores and litter samples.

Pine needles were exposed to tritium under controlled conditions as follows. Freshly excised loblolly pine branches were sealed in a neck of a glass flask using a split rubber stopper and rubber cement. For 10-15 minutes, a flow of moist air containing HT was directed over the needles, passed through a cold trap, and vented to the atmosphere. Photosynthesis occurs normally under these conditions (8). In most experiments, the needles were exposed to direct sunlight. Water in both the cold trap and the pine needles was analyzed for tritium.

The non-exchangeable bound tritium content of the needles was determined as follows. Two grams of dried needles were ground and repeatedly equilibrated with $10 \mathrm{cc}$ portions of tritium-free water. The needles were then freeze-dried until the tritium in the water removed was reduced to background levels. Samples were then combusted to recover any non-exchangeable bound tritium. Small amounts of non-exchangeable bound tritium were found to be formed during control exposures to HTO vapor. Since HTO is formed in needles exposed to HT, HTO will make a small contribution to the formation of bound tritium, even in branches exposed to HT.

The contribution of HTO synthetic processes to the nonexchangeable organic pool was estimated by exposing branches to HTO vapor. The results of the HTO exposures we re subtracted from 
the non-exchangeable organic tritium before calculating the deposition rate of $\mathrm{HT}$ to the non-exchangeable tritium pool.

\section{Results}

The free tritium and total bound tritium concentrations of leaf litter were determined at a number of locations at varying distances from the separations facility. The results (20 data points) were analyzed by 1 inear regression. The resulting equations are given below.

$$
\begin{array}{lll}
\text { FREE TRITIUM: } & \ln \mathrm{T}=4.27-1.10 \ln \mathrm{D} & \mathrm{r}^{2}=0.75 \\
\text { TOTAL BOUND TRITIUM: } & \ln \mathrm{T}=5.91-0.97 \ln \mathrm{D} & \mathrm{r}^{2}=0.83
\end{array}
$$

$\mathrm{T}=$ tritium concentration in $\mathrm{pCi} / \mathrm{mL}$

$D=$ distance from $\mathrm{H}$ Area in $\mathrm{km}$

These equations are plotted in Figure 1. The atmospheric нTO values from monitoring data are also shown for comparison. At a distance of several kilometers, free tritium levels are generally similar to the tritium levels in atmospheric moisture. Near $\mathrm{H}$ Area, free tritium levels in the litter may be slightly elevated relative to atmospheric moisture. Total bound tritium levels are 5-10 times higher than either free tritium levels or atmospheric HTO levels.

The results of analyses of soil cores (Table 1) indicate that the distribution of free tritium is relatively uniform in the upper meter of soil. In contrast, there are higher levels of total bound tritium in the leaf litter than in the soil. This difference is most apparent in litter samples taken near the H-Area separations facility. 
In an attempt to determine if the total bound tritium was associated with any specific class of needle organic compounds, fresh pine needles and pine litter were treated with benzeneethanol. Benzene-ethanol removes extractives, a heterogeneous group of compounds including fats, oils, resins, and phenolics. The results of combustion and tritium analysis of the resulting water are given in Table II. Total bound tritium is concentrated in the extractive fraction. The residue was lower in tritium, but still above average levels of ambient HTO (Figure 1).

Several controlled exposures were carried out using soil, pine litter, and excized living pine branches to determine whether synthesis of tritium into the non-exchangeable bound tritium fraction of organic compounds contributes to the total bound tritium. Deposition velocities (relative deposition rates) were calculated using the following formula:

$$
\begin{aligned}
V_{d}=\frac{T}{C \times A \times t} \\
V_{d}=\text { deposition velocity }(\mathrm{cm} / \mathrm{sec}) \\
T=\text { total tritium reacted }(\mathrm{pCi}) \\
\mathrm{C}=\text { air tritium concentration }(\mathrm{pCi} / \mathrm{cc}) \\
\mathrm{A}=\text { needle area }\left(\mathrm{cm}^{2}\right) \\
\mathrm{t}=\text { time (sec) }
\end{aligned}
$$

Values for deposition velocities are shown in Table III. Soil and leaf litter readily oxidize HT to free tritium, but synthesis of non-exchangeable bound tritium is lower than we are able to detect. Living pine needles form free tritium much more slowly, but a measurable amount of HT is converted to a non-exchangeable bound form. 
There are two differences between deposition processes for free and non-exchangeable bound tritium in pine needles. The first is that formation of free tritium is strongly inhibited in the dark while formation of bound tritium is increased. The second difference is that the deposition velocity of free tritium formation is independent of HT concentrations while deposition velocity of formation of non-exchangeable bound tritium decreases at higher HT concentrations as shown in Figure 2.

The observed constant deposition velocity for this process is consistent with a deposition process which is limited by diffusion into the needle. The constant deposition velocity over the range of air concentrations used in the exposures means that the deposition rate is 1 inearly related to the concentration gradient between the atmosphere and the oxidation site in the needle.

The process incorporating tritium into non-exchangeable bound sites is not sensitive to decreases in the internal tritium concentration caused by stomatal closure or decreases in external tritium concentrations. This response suggests a process that is 1 imited by the number of active chemical sites, such as an enzyme mediated reaction. However, this explanation does not account for the increase in non-exchangeable bound tritium in the dark. It is possible that the oxidation of HT to HTO requires light and does not compete with the process incorporating HT into the nonexchangeable bound sites in the dark. This cannot be confirmed since we do not know the chemical processes by which the deposition takes place. 


\section{Discussion}

In a system which is exposed to tritium only in the form of tritiated water, all the exchangeable hydrogen sites would quickly come into equilibrium with the tritiated water. The nonexchangeable sites in material synthesized from HTO or undergoing chemical exchange processes with HTO would also be nearly in equilibrium. The small isotopic discrimination factors for most chemical processes involving tritiated water would serve to lower the tritium content of the material slightly (9).

However, if synthetic or chemical exchange processes are taking place simultaneously with some other tritiated compound, such as HT, with a different isotopic composition, then the material will have an isotopic composition intermediate to the two sources of tritium.

It is well known that a variety of synthetic and exchange processes in living plants and microorganisms involve water. This paper has demonstrated that HT is also involved in some process leading to synthesis of organic matter. The relative amount of tritium in atmospheric hydrogen is higher than that in atmospheric water despite the smaller absolute amount of tritiated hydrogen because of the much smaller amount of natural hydrogen in the atmosphere. Therefore, it is reasonable to expect the concentration of tritium in organic matter synthesized from hydrogen to be greater than the water in the organism which is freely exchanged with the tritiated water in the environment. 
Bogen and Welford (10) found relatively high levels of tritium in the water from combustion of dried surface soils. They determined that there is a small discrimination against deuterium in the bound water fraction of soil. They inferred from this that the source of tritium in this fraction must be different than that for deuterium. The anomalously high levels of bound tritium found in soil at SRP and elsewhere may be related to HT metabolism by plants and soil microbes.

Microorganisms in soil and surface litter can readily oxidize HT to HTO. Soil uptake of HT may make a contribution to free tritium levels adjacent to the H-Area separations facility at SRP. Average levels there are somewhat higher than would be expected from HTO alone (Figure 1). However, there is no measurable formation of bound tritium during HT oxidation by soil and litter microbes.

Although the conversion rate of HT to HTO is much slower in pine needles than in soil, this process may still be important for a forested area because the needle surface area of a pine stand can be 10-20 times that of the soil. In addition, wind speeds are higher in the tree canopy than at the soil surface, and higher windspeeds are known to increase HT deposition velocity (4). A small fraction of the HT oxidized in pines is converted to an organically bound form. This tritium is concentrated in the extractive fraction of the needles. Litter is very slow to decay (preliminary results indicate no measurable loss after one year). 
Oxidation of atmospheric HT in pine needles thus results in an organically bound form of tritium which remains in the soil for many years. Samples of oak, elm, cherry, and soybean taken near a source of HT also show higher tritium activity in the bound fraction than in free water. Therefore, it appears HT may be the source of elevated bound tritium levels found in surface soils throughout North America (10). 
TABLE I

Tritium in Soil Near H Area

Soil Tritium ( $\left.\mathrm{nCi} / \mathrm{m}^{2}\right)$

\begin{tabular}{|c|c|c|c|c|}
\hline \multirow{2}{*}{$\begin{array}{l}\text { Soil Depth } \\
(\mathrm{cm})\end{array}$} & \multicolumn{2}{|l|}{$2 \mathrm{~km}^{\mathrm{a}}$} & \multicolumn{2}{|l|}{$8 \mathrm{~km}^{\mathrm{a}}$} \\
\hline & Free & Bound & Free & Bound \\
\hline Litter & $250 \pm 170$ & $1100 \pm 550$ & $60 \pm 20$ & $200 \pm 115$ \\
\hline $0-10$ & $400 \pm 600$ & $150 \pm 250$ & $50 \pm 40$ & $70 \pm 40$ \\
\hline $10-10$ & $150 \pm 125$ & $200 \pm 120$ & $30 \pm 30$ & $60 \pm 35$ \\
\hline $40-50$ & $300 \pm 425$ & $100 \pm 50$ & $30 \pm 10$ & $50 \pm 35$ \\
\hline $90-100$ & $400 \pm 575$ & $50 \pm 25$ & $30 \pm 15$ & $60 \pm 32$ \\
\hline
\end{tabular}

a. Distance from $H$ Area, 5 locations were sampled at each distance. 
TABLE II

Tritium Levels in Fractions Extracted from Pine Needles

\begin{tabular}{|c|c|c|c|c|c|}
\hline \multirow[b]{2}{*}{ Water } & \multirow{2}{*}{$\begin{array}{l}\begin{array}{l}\text { Present Year } \\
\text { Needle }\end{array} \\
79 \pm 6\end{array}$} & \multirow{2}{*}{$\begin{array}{l}\begin{array}{l}\text { Past Year } \\
\text { Needle }\end{array} \\
80 \pm 2\end{array}$} & \multirow{2}{*}{$\begin{array}{l}\text { Bud } \\
-\end{array}$} & \multicolumn{2}{|c|}{ Litter } \\
\hline & & & & 156 & 34 \\
\hline Benzene-Ethano 1* & $421=19$ & $456 \div 105$ & $1334 * *$ & 666 & 54 \\
\hline Residue & $204 \pm 10$ & $243 \therefore 37$ & $423 * *$ & 324 & 68 \\
\hline
\end{tabular}

* Extracts were burned after evaporation of the solvent. Results are the activity of the water of combustion in $\mathrm{pCi} / \mathrm{mL}$

** One sample 
TABLE III

Molecular Tritium Deposition Velocities

Soil

\begin{tabular}{l}
$\begin{array}{l}\text { Free Tritium } \\
(\mathrm{cm} / \mathrm{sec})\end{array}$ \\
\hline
\end{tabular}

Leaf Litter

$1.0 \pm .2 \times 10^{-2}$

Bound Tritium ${ }^{\mathrm{c}}$

$(\mathrm{cm} / \mathrm{sec})$

Pine Needles ${ }^{a}$

$1.1 \pm .3 \times 10^{-2}$

0

0

Pine Needles (Dark)a

$1.2 \pm .2 \times 10^{-5}$

$1.0 \pm .7 \times 10^{-7}$

$0.2 \pm .2 \times 10^{-5}$

$2.6 \pm .3 \times 10^{-7}$

\footnotetext{
a. Light $=100 \mu \mathrm{E} / \mathrm{m}^{2} / \mathrm{sec}$, Dark $=0.3 \mu \mathrm{E} / \mathrm{m}^{2} / \mathrm{sec}$ at $400-700 \mathrm{~mm}$

b. Tritium in freeze-dry water plus exchangeable organic tritium, $n=5$

c. Non-exchangeable organic tritium, $n=5$
} 


\section{REFERENCES}

(1) Burger, L. L. Distribution and Reactions of Tritiated Hydrogen and Methane in "Behavior of Tritium in the Environment" IAEA, Vienna, 1979, p. 47-64.

(2) Mason, A. S., Ostlund, H. G. Atmospheric HT and HTO: V. Distribution and Large-Scale Circulation in "Behavior of Tritium in the Environment" IAEA, Vienna, 1979, p. 3-16.

(3) McFarlane, J. C., Rodgers, D., Bradley, D. V. Environ Sci and Tech. 12, 590-592 (1978).

(4) Sweet, C. W. and Murphy, C. E., Jr. Environ Sci and Tech. $15,1485-1487(1981)$.

(5) Murphy, C. E., Jr., and Pendergast, M. M. Environmental Transport and Cycling of Tritium in the Vicinity of Atmospheric Releases in "Behavior of Tritium in the Environment." IAEA, Vienna, 1979, pp. 361-372.

(6) Garland, S. A., and Cox, L. C. Water, Air and Soil Pollut. $14,102-114(1980)$

(7) Murphy, C. E., Jr., Watts, J. R., and Corey, J. C. Health Physics 33, 325-331 (1977).

(8) Anclair, D. Forest Sci. 25, 72-79 (1979).

(9) Weston, R. E. Kinetic and Equilibrium Isotope Effects of Tritium Substitution in "Tritium," A. A. Moghissi and M. W. Carter, eds, Las Vegas, Messenger Press, pp. 289-303 (1973).

(10) Bogen, D.C., and Welford, G. A. Health Physics 30, 203-208 (1976). 


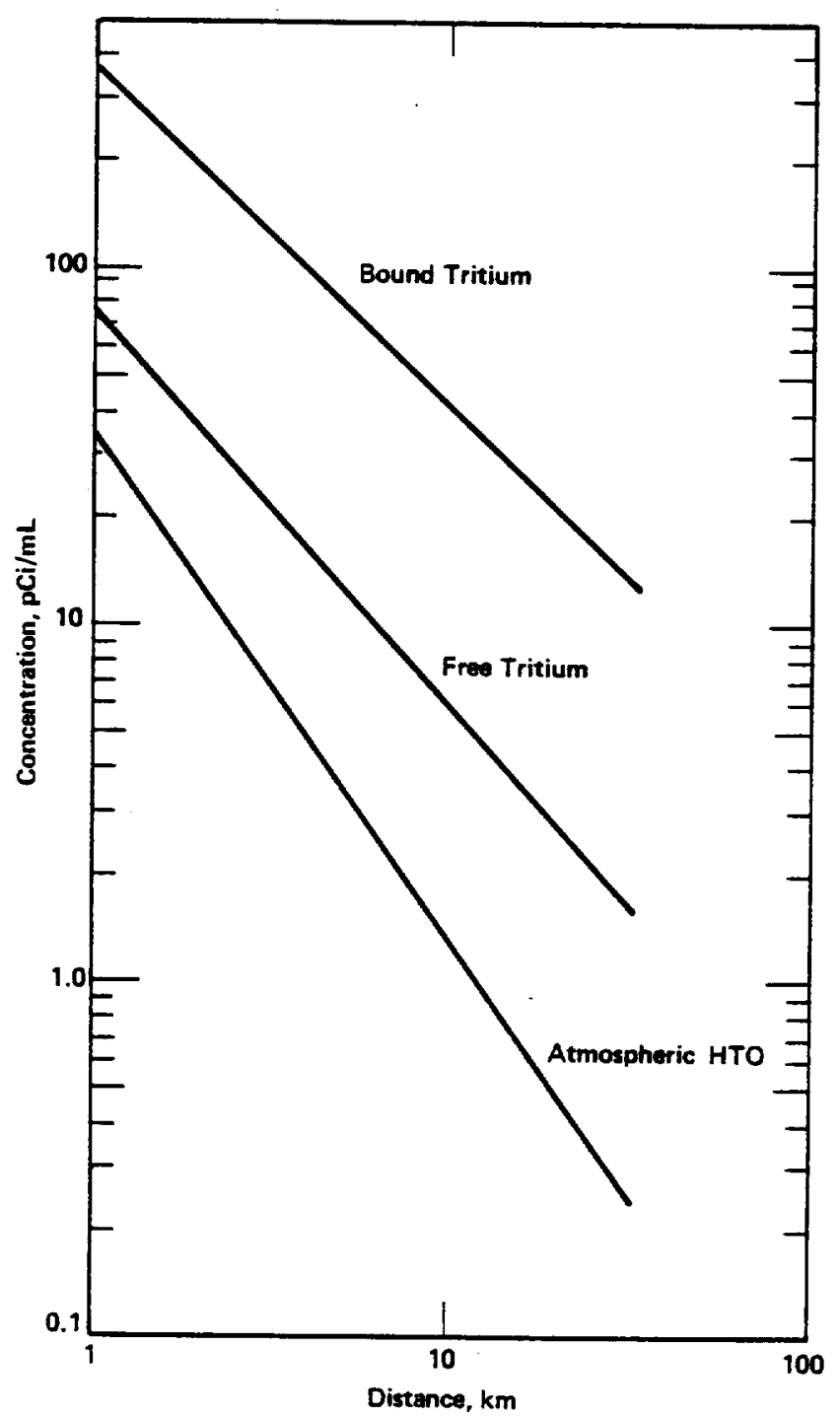

PIGURE 1

Tritium in leaf litter near H-Area 


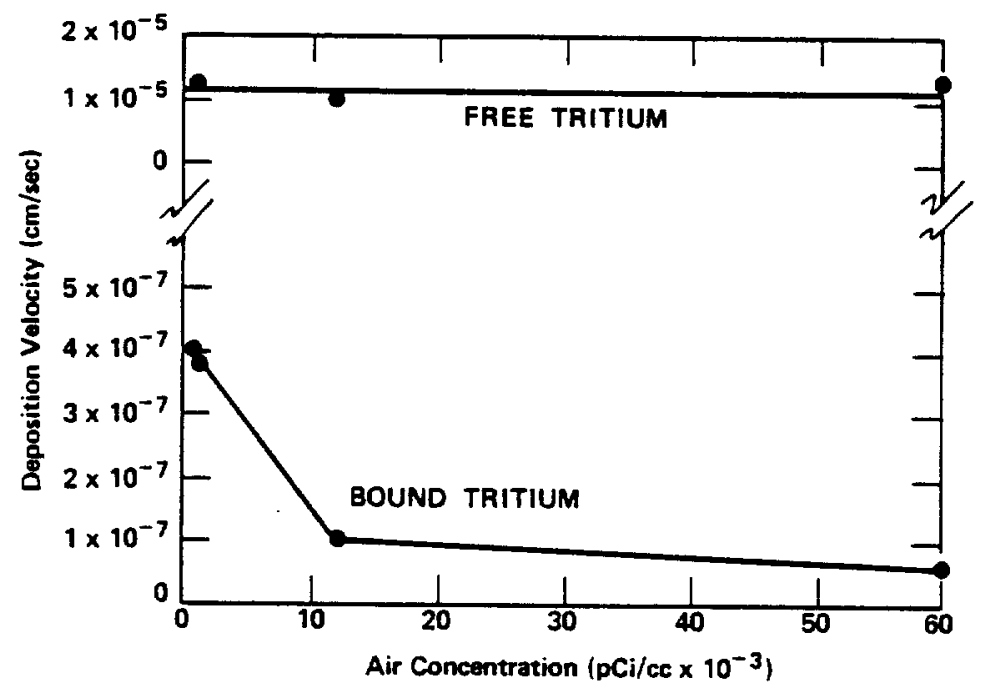

FIGURE 2

Effect of tritium concentration on deposition velocity 


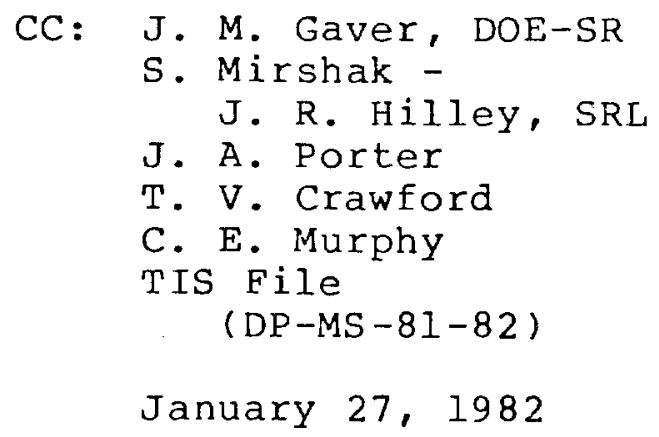

TO DISTRIBUTION

Attached is a copy of the following:

DP-MS-81-82, "Tritium Deposition in Pine Trees and Soil from Atmospheric Releases of Molecular Tritium" by C. W. Sweet and C. E. Murphy.

This paper is proposed for publication in Environmental Science and Technology.

If there are comments about its release, notify the TIS office within 14 days (Ext. 3598).

For any technical clarification, we suggest you call:

T. V. Crawford, Research Manager

Environmental Sciences Division

Savannah River Laboratory 